\title{
Location of an Intron in the Cytochrome $b$ Gene Indicates Reduced Risk of Qol Fungicide Resistance in Fusicladium effusum
}

\author{
J. R. Standish, H. F. Avenot, T. B. Brenneman, and K. L. Stevenson, Department of Plant Pathology, Coastal Plain Experiment Station, \\ The University of Georgia, Tifton 31793
}

\begin{abstract}
Standish, J. R., Avenot, H. F., Brenneman, T. B., and Stevenson, K. L. 2016. Location of an intron in the cytochrome $b$ gene indicates reduced risk of QoI fungicide resistance in Fusicladium effusum. Plant Dis. 100:2294-2298.

Pecan scab, caused by Fusicladium effusum, is most effectively managed using multiple fungicide applications, including quinone outside inhibitors (QoIs). However, QoIs have a high risk for resistance developing in phytopathogenic fungi. QoI resistance is generally associated with amino-acid substitutions at positions 129,137 , and 143 of the cytochrome $b$ (cytb) gene. A substitution at position 143 confers complete resistance, while an intron immediately downstream of this position prevents the substitution. The objective of this study was to assess the risk of QoI resistance by characterizing a partial fragment of the $F$. effusum cytb gene. Sequence

analysis of the 1,919-bp fragment revealed the presence of a 1,407-bp intron immediately downstream of position 143 . This intron was identified in 125 isolates collected from 16 counties across the state of Georgia. No substitutions were identified at positions 129 or 143 but, in seven of the isolates, glycine was replaced with serine at position 137 . The ubiquitous nature of the detected intron provided strong evidence that the G143A substitution may not occur in $F$. effusum isolates, although resistance could still develop through intron loss events or the selection of intron-lacking genotypes, or as the result of other mutations in the $c y t b$ gene.
\end{abstract}

Pecan scab, caused by the fungus Fusicladium effusum G. Winter, is the most destructive disease affecting pecan (Carya illinoinensis (Wangenh.) K. Koch) (Demaree 1924). F. effusum is a slow-growing fungus and a member of the family Venturiaceae with an unknown sexual stage (Beck et al. 2005; Seyran et al. 2010c). Scab occurs as lesions on leaves, fruit shucks, and twigs. Young, actively growing tissues are most susceptible to infection and become resistant to infection as they mature (Demaree 1924; Littrell and Bertrand 1981). Small olivebrown to black spots of approximately 1 to $5 \mathrm{~mm}$ in diameter will appear on infected plant material, and these spots may expand and coalesce to form large, irregularly shaped lesions. Sporulating lesions have a velvety or rough appearance (Bertrand 2002; Demaree 1924). Shuck infections that occur between fruit set and shell hardening can cause severe yield loss. Fruit infections that occur during the early stages of fruit development can cause premature fruit drop, although infections that occur after the shell has hardened are thought to be more cosmetic than damaging (Bertrand 2002; Demaree 1924; Hunter 1983).

The use of resistant cultivars is the most practical method of managing scab. However, host resistance is not permanent because cultivar-specific physiological races of $F$. effusum are known to exist and, over the years, have developed on cultivars once thought to be highly scab resistant (Demaree and Cole 1929; Sparks 1992). In the absence of varietal resistance, the most effective scab management practice is to make multiple preventive fungicide applications throughout the growing season (Brock and Bertrand 2007b). Fungicides are typically sprayed on a calendar schedule but the interval between sprays is often adjusted based on weather conditions (Latham 1995). The general guideline in Georgia calls for 7 to 10 fungicide applications per season, made at 10- to 14-day intervals from bud break until pollination, and at 14- to 21-day intervals from pollination to shell hardening (Brock and Bertrand 2007a). During rainy periods, fungicides may be applied every 7 to 10 days, which can substantially increase the total number of applications per season. Fungicides from different chemical groups are approved for use on pecan in the

Corresponding author: K. L. Stevenson; E-mail: ks@uga.edu

Accepted for publication 21 June 2016.

http://dx.doi.org/10.1094/PDIS-05-16-0658-RE

(c) 2016 The American Phytopathological Society
United States and include the quinone outside inhibitors (QoI), demethylation inhibitors (DMI), methyl benzimidazole carbamates (MBC), guanidines, and organotin compounds (Fungicide Resistance Action Committee [FRAC] Code 11, 3, 1, U12, and 30, respectively) (Brock et al. 2007).

The QoI fungicides are a major tool in scab management both as premix combinations, most often with a DMI, and as stand-alone products. Several stand-alone QoI fungicides are commercially available and labeled for use on pecan in the United States, most notably azoxystrobin (Abound 2.08F; Syngenta Crop Protection, Greensboro, NC), kresoxim-methyl (Sovran 50WG; BASF Corporation, Research Triangle Park, NC), and pyraclostrobin (Headline 2.09F; BASF Corporation) (Brock et al. 2007). FRAC classifies the QoIs as being "high-risk" for developing resistance in fungal populations due to their single-site mode of action (FRAC 2016). The fungicides in this group inhibit mitochondrial respiration by binding to the quinol oxidation site of the cytochrome $b c_{1}$ enzyme complex, blocking electron transfer between the cytochrome $b(c y t b)$ and cytochrome $c_{1}$ genes (Bartlett et al. 2002; Gisi et al. 2002). This process halts the production of ATP, resulting in an energy deficiency in fungal cells (Fernández-Ortuño et al. 2008).

Resistance to the QoI fungicides was first detected in isolates of Blumeria graminis (DC.) Speer f. sp. tritici identified in 1998 in Germany (Bartlett et al. 2002). Since that time, field resistance has been documented in over 30 species representing 20 genera (FRAC 2013) and primarily occurs as a result of nucleotide point mutations in the cytb gene (Fernández-Ortuño et al. 2008). These mutations lead to specific amino-acid substitutions and have been detected in an area of the cytb gene corresponding to amino-acid positions 120 to 155 of the encoded protein. Within this specific region, three substitutions have been detected in QoI-resistant plant-pathogenic fungi and oomycetes. A substitution from glycine to alanine at position 143 (G143A) is known to confer complete resistance to the QoI fungicides and is associated with a failure to inhibit the pathogen (Fernández-Ortuño et al. 2008). Additionally, substitutions from phenylalanine to leucine at position 129 (F129L) or from glycine to arginine at position 137 (G137R) have been associated with reduced sensitivity but the pathogen usually can be managed by more frequent applications or increased rates of the QoI fungicides (Fernández-Ortuño et al. 2008; Gisi et al. 2002; Sierotzki et al. 2007). Due to their common mode of action, cross-resistance within this class of chemicals is frequently observed in fungi carrying 
amino-acid substitutions so that, if resistant to one QoI active ingredient, the fungus will be resistant to all QoI active ingredients (Fernández-Ortuño et al. 2008; Sierotzki et al. 2000).

An alternative cyanide-resistant respiration pathway sustained by alternative oxidase (AOX) has been shown to serve as a rescue mechanism for some plant pathogens in the presence of a QoI fungicide (Fernández-Ortuño et al. 2008; Wood and Hollomon 2003). When AOX occurs, mitochondrial electron transfer is diverted by circumventing the inhibitory site of the QoI. This alternative pathway seems to provide enough energy to counteract the effects of QoI in vitro but not in planta (Wood and Hollomon 2003). Characteristic inhibitors of AOX in vitro include salicylhydroxamic acid (SHAM) and propyl gallate (PG) (Schonbaum et al. 1971; Siedow and Bickett 1981).

In 2014, a fungicide sensitivity monitoring program was initiated in Georgia that allowed pecan growers to submit leaf samples exhibiting symptoms of pecan scab for orchard-specific testing. Sensitivities to dodine, fentin hydroxide, thiophanate-methyl, propiconazole, and tebuconazole were determined using a rapid in vitro method described by Seyran et al. (2010a). Samples were also tested for sensitivity to azoxystrobin; however, SHAM and PG have been shown to exhibit fungitoxic effects on $F$. effusum in vitro, making the results of such a test unreliable (Seyran et al. 2010b). Due to the inability of an in vitro bioassay to accurately quantify sensitivity to the QoI, coupled with the very slow growth rate of the pathogen in culture, a molecular method may provide a more practical and accurate means of monitoring the effectiveness of this important class of fungicide. Additionally, the presence of an intron immediately downstream of position 143 has been found to prevent the formation of the G143A substitution in plantpathogenic fungi, presumably mitigating the risk of resistance (Grasso et al. 2006a; Luo et al. 2010; Sierotzki et al. 2007).

The objectives of this study were to sequence and characterize a partial fragment of the $F$. effusum cytb gene and assess the risk of QoI-resistance developing by (i) screening for the amino-acid substitutions known to confer resistance to the QoI fungicides and (ii) determining the presence or absence of an intron immediately downstream of position 143 in isolates collected from pecan orchards in Georgia.

\section{Materials and Methods}

Collection of $\boldsymbol{F}$. effusum isolates. Samples of pecan leaflets showing symptoms of scab were collected by individual growers and submitted to the University of Georgia Coastal Plain Experiment Station in Tifton. Each sample was divided into three groups of 15 leaflets and conidia were collected using a protocol described by Seyran et al. (2010b). To confirm pathogen identity, leaf lesions were examined using a stereomicroscope to identify the conidia of $F$. effusum. Species confirmation was initially based on conidial morphology using light microscopy $(\times 100)$; additionally, isolates were positively identified after sequencing and analysis of the internal transcribed spacer (ITS) region (Bertrand 2002; White et al. 1990).

Monoconidial isolates were established from each group per sample by pipetting $19 \mu \mathrm{l}$ of the corresponding spore suspension onto water agar (15 $\mathrm{g}$ of agar per liter of water) amended with tetracycline (50 mg/liter), streptomycin sulfate $(50 \mathrm{mg} / \mathrm{liter})$, and chloramphenicol $(50 \mathrm{mg} /$ liter) in petri plates ( 15 by $100 \mathrm{~mm}$ in diameter). The spore suspension was then spread across the surface with a sterile glass rod. Two replicate plates were prepared per sample. After $24 \mathrm{~h}$, three germinated conidia per sample were aseptically transferred to petri plates containing potato dextrose agar made with the previously stated antibiotic amendments. Monoconidial isolates were placed in an incubator at $25^{\circ} \mathrm{C}$ to allow for colony growth.

Genomic DNA and RNA isolations and cDNA synthesis. Genomic DNA was extracted from mycelia for $125 \mathrm{~F}$. effusum isolates obtained from infected samples collected in 2014. Isolates were grown on agar medium as previously described; mycelia and conidia were collected after 6 to 8 weeks of incubation by scraping the colony surface with a sterile blade. Genomic DNA was extracted and purified using a ZR Fungal/Bacterial DNA MicroPrep Kit (Zymo Research Corp., Irvine, CA) according to the manufacturer's instructions.

For RNA isolation, mycelia for six $F$. effusum isolates were grown in $100 \mathrm{ml}$ of potato dextrose broth for 4 days at $24^{\circ} \mathrm{C}$. Mycelia were removed from the broth, rinsed with sterile distilled water, and dried before being ground to a fine power in liquid nitrogen using a mortar and pestle. Total RNA was extracted from mycelia using the RNeasy Plant Mini Kit (Qiagen, Valencia, CA) following the manufacturer's instructions. RNA samples were subsequently treated with DNase I Amp Grade (Invitrogen, Carlsbad, CA) according to the manufacturer's protocol. The first-strand complementary DNA (cDNA) was then synthesized from $5 \mu \mathrm{g}$ of total RNA using the ThermoScript reverse-transcription polymerase chain reaction (PCR) system (Invitrogen) following the manufacturer's instructions.

Cloning of a partial cytochrome $b$ gene fragment from F. effusum isolates. A degenerate primer set was designed based on highly conserved regions of $c y t b$ gene sequences from several fungi; namely, Venturia inaequalis (Cooke) G. Winter (GenBank accession number AF004559), Cercospora beticola Sacc. (GenBank accession number JQ360628), C. kikuchii (Tak. Matsumoto \& Tomoy.) M. W. Gardner (GenBank accession number AB231863), Mycosphaerella graminicola (Fuckel) J. Schröt (GenBank accession number AY247413), and Alternaria alternata (Fr.) Keissl. (GenBank accession number DQ209283). These primers-PecFwd (5'-GAGGKYTATATTAYGGTTCTTAYA GAG-3') and PecRev (5'-GAGTTTGCATAGGGTTAGCTA-3')-were used to amplify an approximately 450-bp partial fragment of the cytb gene from the first-strand cDNA in $F$. effusum. ThermoPrime DNA polymerase (Invitrogen) was used in PCR heated at $95^{\circ} \mathrm{C}$ for $3 \mathrm{~min}$, followed by 40 cycles of amplification $\left(94^{\circ} \mathrm{C}\right.$ for $15 \mathrm{~s}, 50^{\circ} \mathrm{C}$ for $30 \mathrm{~s}$, and $72^{\circ} \mathrm{C}$ for $30 \mathrm{~s}$ ), and a final extension at $72^{\circ} \mathrm{C}$ for $5 \mathrm{~min}$. The PCR products for the six $F$. effusum isolates were visualized by electrophoresis in $1.0 \%$ agarose gels and purified using a Geneclean kit (MP Biomedicals, Santa Ana, CA). The purified products were cloned into the pGEM-T Easy Vector (Promega Corp., Madison, WI) and sequenced in both directions at the University of Georgia Genomics Facility. The nucleotide sequences for two isolates, 4_PeS and 10_PeS, were deposited into GenBank (accession numbers KT427434 and KT427435, respectively).

Molecular characterization of $\boldsymbol{F}$. effusum isolates. Isolates were positively identified based on nucleotide sequences of the ITS region of three representative F. effusum isolates: 14-49, 14-73, and 14-174. PCR amplification was performed using an ITS4/ITS5 primer set (White et al. 1990).

The primers PS1 (5'-GTTACAGCCTTCCTGGGTTAT-3') and PR1 (5'-AGGCCTCCCCACAGAAATTCG-3'), described by Fontaine et al. (2009) for use with the closely related fungus $V$. inaequalis, were used to amplify a partial fragment of the $c y t b$ gene corresponding to the binding site of the QoI fungicides. Using the resultant sequences and the cDNA sequences previously described, primer sets FeCytb_F1 (5'-GAGCACCTAGAACGTTAGTGTGA-3') and FeCytb_R1 (5'-AACCAGACGGGCTCTAATGG-3'), FeCytb_F2 (5'-TGTTTGTTGGTCTAGTAGATGGGG-3') and FeCytb_R2 (5'GCTAACCAAGACGCACCTGTA-3'), and FeCyb_F3 (5'-AGG TAACTTCGGACAATGTACTG-3') and FeCytb_R3 (5'-TCACGCT GAAACCTCCTCAC-3') were designed to amplify a region that would allow for the detection of nucleotide point mutations at positions 129 (F129L), 137 (G137R), and 143 (G143A). These same primers allowed for the identification of introns within the partial gene fragment.

PCR was carried out in a Mastercycler Thermal Cycler (Eppendorf AG, Hamburg, Germany) with $1 \times$ GoTaq Buffer (Promega Corp.), $2 \mathrm{mM} \mathrm{MgCl}, 0.2 \mathrm{mM}$ dNTPs, $0.1 \mu \mathrm{M}$ forward and reverse primer, $1 \mathrm{U}$ of GoTaq polymerase, and genomic DNA at 20 to $80 \mathrm{ng} / \mu \mathrm{lin}$ a final reaction volume of $25 \mu$ l. The cycling conditions for all primer sets were an initial denaturation period at $94^{\circ} \mathrm{C}$ for $3 \mathrm{~min}, 35$ cycles of amplification $\left(94^{\circ} \mathrm{C}\right.$ for $30 \mathrm{~s}, 55^{\circ} \mathrm{C}$ for $45 \mathrm{~s}$, and $72^{\circ} \mathrm{C}$ for $\left.50 \mathrm{~s}\right)$, and a final extension at $72^{\circ} \mathrm{C}$ for $10 \mathrm{~min}$. PCR products were visualized by electrophoresis in $1.5 \%$ agarose gels and purified using a QiaQuick PCR Purification Kit (Qiagen) per the manufacturer's instructions. Amplicons were submitted to Eurofins MWG Operon LLC, Louisville, $\mathrm{KY}$ for custom sequencing. Nucleotide sequences were trimmed and contigs were assembled using the BioEdit software package version 7.2.5 (Hall 1999). Alignment and analysis were performed using Clustal W within MEGA6 (Tamura et al. 2013). 


\section{Results}

Collection of $F$. effusum isolates and genomic DNA extraction. In total, 125 monoconidial isolates were obtained from samples submitted from orchards in 16 different counties across the state of Georgia (Table 1). Genomic DNA was extracted successfully from all isolates collected for this study.

Table 1. Origin and number of Fusicladium effusum isolates collected from pecan in 2014 and used in this study

\begin{tabular}{lcc}
\hline & \multicolumn{2}{c}{ Number of isolates } \\
\cline { 2 - 3 } County $^{\mathbf{a}}$ & Collected & With G137S $^{\mathbf{b}}$ \\
\hline Appling & 1 & 0 \\
Bleckley & 5 & 0 \\
Brooks & 1 & 0 \\
Burke & 1 & 0 \\
Crisp & 8 & 1 \\
Dougherty & 8 & 1 \\
Jeff Davis & 1 & 0 \\
Lanier & 12 & 0 \\
Lee & 1 & 0 \\
Lowndes & 5 & 0 \\
Mitchell & 1 & 0 \\
Peach & 5 & 1 \\
Stewart & 1 & 1 \\
Sumter & 3 & 1 \\
Terrell & 3 & 1 \\
Tift & 69 & 1 \\
Total & 125 & 7 \\
\hline
\end{tabular}

a Counties in Georgia.

${ }^{b}$ Isolates carrying the G137S amino-acid substitution determined by comparing nucleotide sequences.
Molecular characterization of $\boldsymbol{F}$. effusum isolates. The nucleotide sequences of the ITS region of three representative isolates (14-49, 1473 , and 14-174) were mutually identical and shared $100 \%$ homology to the corresponding genomic region of $F$. effusum strain STE-U 4525 (GenBank accession number AY251085). The nucleotide sequences of 14-49, 14-73, and 14-174 were deposited into GenBank (accession numbers KT387749 to KT387751).

Primers PS1 and PR1 successfully amplified a single DNA band of 1,840 bp which, upon sequencing, shared $99 \%$ homology with a 409-bp portion of the corresponding region in $V$. inaequalis (GenBank accession number AF004559). This primer set was expected to amplify a region of approximately $400 \mathrm{bp}$ and, because the resulting amplicon was $>1,800 \mathrm{bp}$, three new primer sets were designed to amplify the larger fragment in three overlapping sections. Primer pairs FeCytb_F1/FeCytb_R1, FeCytb_F2/FeCytb_R2, and FeCytb_F3/ FeCytb_R3 successfully amplified three single DNA bands (excluding primer regions) of 619,883 , and $508 \mathrm{bp}$, respectively. These overlapping fragments were combined to form consensus sequences that were analyzed for 20 individual isolates. The resulting fragment of 1,919 bp (excluding primer regions), spanning amino-acid positions 115 to 164, revealed the presence of two introns (Fig. 1A).

The first intron ( $360 \mathrm{bp}$ ) was observed immediately downstream of the codon for proline at position 135 and shared $99 \%$ homology with an intron of the same size found at the same position in $V$. inaequalis (GenBank accession number AF004559). A short exon (24 bp) separated the first intron from a second intron $(1,407 \mathrm{bp})$ that was identified directly downstream of the codon for glycine at position 143 . A BLAST search of the predicted amino-acid sequence of this 1,407-bp intron in the Non-Redundant Protein Sequence Database (nr) revealed the presence of a putative conserved domain belonging to the LAGLIDADG endonuclease superfamily; however, high homology $(>70 \%)$ was not identified and only a few minor similarities were noted $(>40$ to $<70 \%)$. The nucleotide sequences of the entire 1,919-bp

A

115

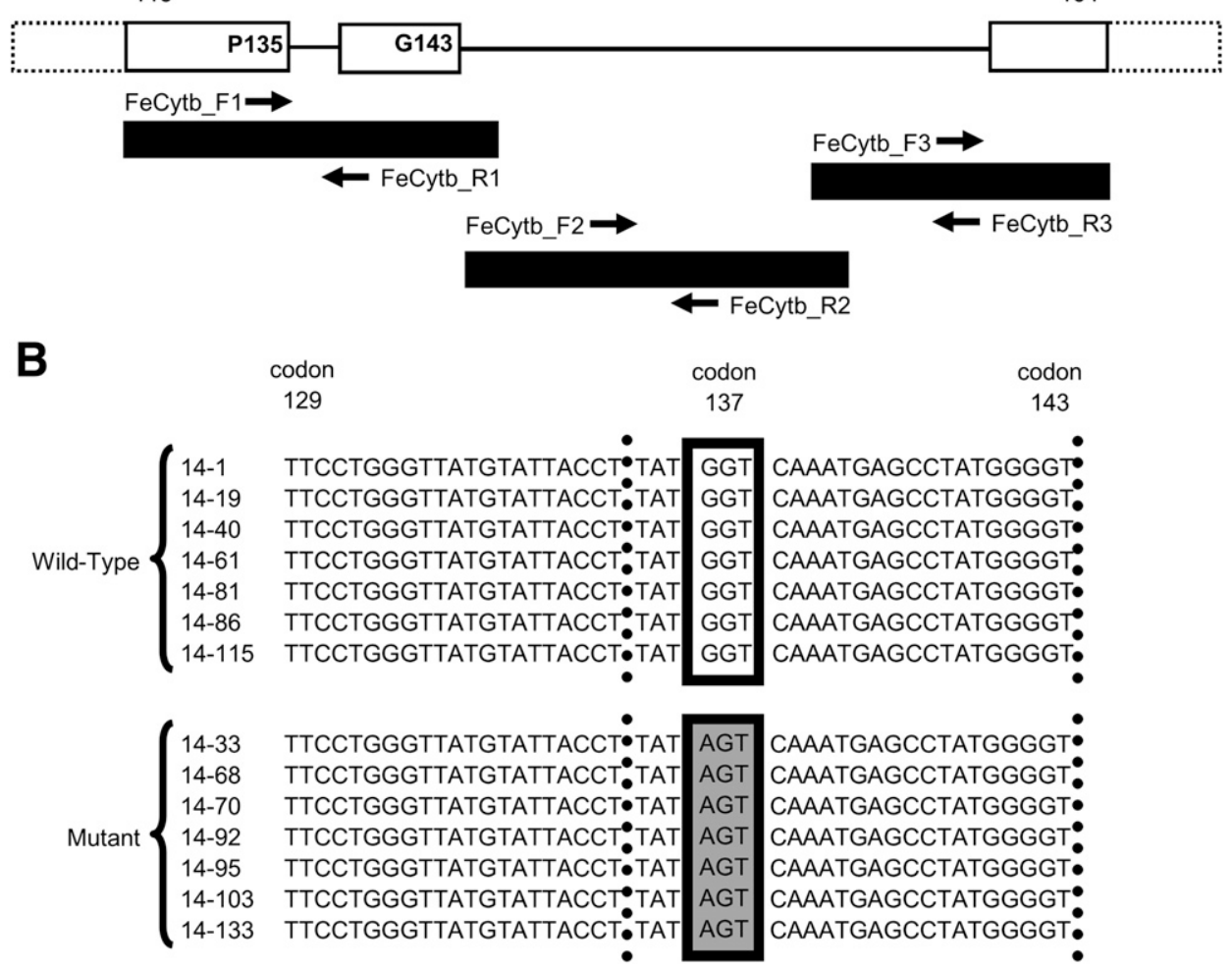

Fig. 1. Partial characterization of the Fusicladium effusum cytochrome $b$ (cytb). A, Structure of the partial cytb fragment. Empty boxes indicate exons and lines indicate introns. Dashed boxes represent nonsequenced parts of the gene. Solid black boxes illustrate the three overlapping amplicons used to identify the gene structure. Figure is not to scale. B, Partial nucleotide sequences of the cytb gene. Codon 137 is boxed, and the gray shading indicates the mutation responsible for the G137S amino-acid substitution. Vertical dotted lines represent the position of the two introns indicated in $\mathrm{A}$. 
fragment encompassing both introns for isolates 14-17, 14-28, 14-49, 14-88, and 14-177 were deposited into GenBank (accession numbers KT387752 to KT387756).

The primers FeCytb_F1/FeCytb_R1 were designed with the reverse primer beginning $192 \mathrm{bp}$ inside of the intron downstream of position 143. As such, this primer set amplified a band of $619 \mathrm{bp}$ which allowed for the identification of mutations in the remaining 105 $F$. effusum isolates, in addition to positively confirming the presence of both introns in all isolates prior to sequencing. Sequence analysis of these PCR products revealed the presence of triplets coding for phenylalanine $(\mathrm{F})$ at position 129 and glycine $(\mathrm{G})$ at position 143 . However, in seven isolates, a single nucleotide mutation $(\mathrm{G} \rightarrow \mathrm{A})$ was identified in the codon corresponding to position 137 of the $c y t b$ gene (GGT $\rightarrow$ AGT). This mutation resulted in an amino-acid substitution from glycine to serine (G137S; Fig. 1B). No other differences in nucleotide sequences resulting in amino-acid substitutions, specifically F129L and G143A, were observed in isolates of F. effusum used in this study.

Partial nucleotide sequences of the cytb gene for the seven $F$. effusum isolates carrying a G137S substitution (14-33, 14-68, 14-70, 1492, 14-95, 14-103, and 14-133) and seven wild-type $F$. effusum isolates (14-1, 14-19, 14-40, 14-61, 14-81, 14-86, and 14-115) studied in this work were deposited into GenBank (accession numbers KT387757 to KT387770).

\section{Discussion}

The standard pecan scab management protocol is based on the use of multiple preventive fungicide applications (Demaree and Cole 1929). The fungicides labeled for pecan belong to different chemical groups that include the QoI, DMI, MBC, guanidines, and organotin compounds (Brock et al. 2007). The inherent risk of resistance developing in $F$. effusum to the active ingredients within each of these groups ranges from "low to medium" to "high" (FRAC 2016), which makes screening isolates to determine their sensitivity profiles of the utmost importance. Isolates of $F$. effusum resistant to the MBC active ingredient benomyl were first reported in 1975 after just 3 years of effective control (Littrell 1976). Additionally, a significant reduction in sensitivity to DMI active ingredients was detected when comparing monoconidial isolates from 1995 to those collected in 2003 (Stevenson et al. 2004). To date, even though QoIs are considered high-risk for resistance development and have been used on pecan for several years, practical resistance to these fungicides has not been reported. Additionally, shifts in fungicide sensitivity have not been identified in isolates of $F$. effusum, although a reliable screening method does not currently exist.

The initial focus of this study was to determine whether point mutations associated with QoI resistance in other fungi were present in a partial fragment of the $F$. effusum cytb gene. The investigation concentrated on an area of the gene corresponding to amino-acid residues 115 to 164 . Within this region, several nucleotide mutations leading to amino-acid substitutions can occur that are known to confer resistance to the QoI fungicides, although the level of resistance varies with each substitution. The most important change, occurring at position $143(\mathrm{G} 143 \mathrm{~A})$, is known to confer complete resistance, while a substitution at position 129 (F129L) or 137 (G137R) has been associated with moderate or partial resistance (Fernández-Ortuño et al. 2008; Gisi et al. 2002; Sierotzki et al. 2007). In this study, nucleotide mutations resulting in the G143A and F129L substitutions were not identified; however, a polymorphism in the first position of the codon corresponding to residue $137(\mathrm{G} \rightarrow \mathrm{A})$ resulting in an aminoacid substitution from glycine to serine (GGT $\rightarrow$ AGT) was identified in 7 of the $125 \mathrm{~F}$. effusum isolates screened. To our knowledge, this is the first report of a substitution from glycine to serine at this position in a phytopathogenic fungus. Sierotzki et al. (2007) reported that isolates of Pyrenophora tritici-repentis (Died.) Dreschsler carrying a substitution at position 137 (G137R) exhibited decreased sensitivity when compared with the wild-type isolates but this insensitivity was considered to be a form of partial resistance, similar to that caused by the F129L substitution also reported in that work. The mutation leading to the amino-acid substitution occurred at the first nucleotide of codon 137 in isolates of $P$. tritici-repentis and the isolates of $F$. effusum used in this study (Sierotzki et al. 2007). Thus, it would appear that, with a shift from $\mathrm{G} \rightarrow \mathrm{A}$ in the first position of the codon, the potential for other amino acids to replace glycine would be specific to the triplet coding for glycine in that gene, within a particular species. Nucleotide shifts resulting in different amino-acid substitutions at position 137, such as G137V and G137E, in nonphytopathogenic organisms were found to reduce the respiratory capacity of the organism, indicating that there may be a potential fitness penalty associated with a mutation at this position (Brasseur et al. 1996; Fisher and Meunier 2001). Without a reliable in vitro method to identify phenotypic characteristics, the G137S substitution could not be properly characterized in the $F$. effusum isolates used in this work. Therefore, future studies are necessary to characterize the isolates and determine the relevance of this substitution in $F$. effusum.

A major finding of this research was the presence of a 1,407-bp intron just downstream of the codon for glycine at position 143 in all 125 isolates of $F$. effusum examined in this study. This provided strong evidence that the G143A amino-acid substitution may not occur in isolates of $F$. effusum, because this substitution has only been reported in pathogens not carrying the intron at this position (Grasso et al. 2006a; Sierotzki et al. 2007). An intron adjacent to position 143 has been observed in Alternaria solani Sorauer, Botrytis cinerea Pers., Monilinia fructicola (G. Winter) Honey, M. laxa (Aderh. \& Ruhland) Honey, Phyllosticta ampelicida (Engelm.) Aa, Pyrenophora teres Dreschsler, and several species of rust fungi (Banno et al. 2009; Grasso et al. 2006a,b; Luo et al. 2010; Miessner and Stammler 2010; Miessner et al. 2011; Sierotzki et al. 2007). The intronic sequence downstream of position 143 in isolates of $F$. effusum belongs to the group I intron family (Cech 1988; Lambowitz and Belfort 1993). As has been reported in other organisms, the exonic base immediately upstream of the $5^{\prime}$ splice site was always a $\mathrm{T}$ (U in pre-mRNA) and the base that followed the $3^{\prime}$ splice site was always a G (Banno et al. 2009; Cech 1988; Grasso et al. 2006a; Luo et al. 2010; Sierotzki et al. 2007). Additionally, a BLAST search of the intron sequence revealed the presence of a putative conserved domain belonging to the LAGLIDADG endonuclease superfamily, which has been associated with group I introns (Belfort and Roberts 1997; Heath et al. 1997). Group I introns are able to form an active site to mediate their own removal from mRNA transcripts (Cech 1988). Because splice-site recognition relies on internal guide sequences of the intron that pair with exon sequences, a mutation at the splice site will hinder pairing and the correct excision of the intron (Vallières et al. 2011). Therefore, a nucleotide mutation at a position near an exon/intron junction, such as that which leads to the G143A substitution, would affect the splicing process and lead to a deficient cytb (Cech 1988; Lambowitz and Belfort 1993; Vallières et al. 2011). Mutant isolates carrying the G143A substitution and the aforementioned intron could certainly exist at some point in time although, because of the deficient $c y t b$, these isolates would likely exhibit reduced fitness and quickly disappear from the population (Vallières et al. 2011).

The $c y t b$ gene has been reported to be highly conserved in a single species with regards to the placement of this intron; to date, there has been only one observed exception (Banno et al. 2009; Grasso et al. 2006a,b; Luo et al. 2010; Miessner and Stammler 2010; Miessner et al. 2011; Sierotzki et al. 2007). Banno et al. (2009) identified isolates of B. cinerea from Japan that had two distinct cytb profiles; the first had a group I intron (1,205 bp) downstream of position 143, while the second profile did not possess the intron. Isolates without the intron developed the G143A substitution and, consequently, were found to be highly resistant to the QoI fungicides. Divergent $c y t b$ genotypes could exist in populations of other fungal species such as $F$. effusum but, in this study, the intron was identified in all 125 isolates originating from pecan orchards in 16 counties across the state of Georgia. This provides a strong basis for the assumption that this intron is ubiquitous in the greater $F$. effusum population.

Characterization of this partial fragment of the F. effusum cytb gene is of value as we assess the risk of QoI resistance occurring 
in isolates of this pathogen. The results of this study revealed that a group I intron of $1,407 \mathrm{bp}$ occurs directly downstream of position 143 , the presence of which prevents the occurrence of the G143A amino-acid substitution known to confer complete resistance. Without the potential for this substitution, the risk of QoI resistance developing in the $F$. effusum populations of Georgia would seem to be relatively low. However, even with a reduced risk, resistance may still develop as a result of intron loss events facilitated by reversetranscription-like activity that may lead to the acquisition of the G143A substitution (Vallières et al. 2011). Additionally, selection pressure from repeated or long-term exposure to QoIs could lead to the loss of the intron and the evolution of intron-lacking genotypes harboring the G143A substitution, like those observed in $B$. cinerea (Banno et al. 2009; Vallières et al. 2011).

\section{Acknowledgments}

This research was supported by generous funding provided by the Georgia Agricultural Commodity Commission for Pecan. We thank K. J. Lewis, E. S. McBrayer, and M. J. Roberts for their technical support.

\section{Literature Cited}

Banno, S., Yamashita, K., Fukumori, F., Okada, K., Uekusa, H., Takagaki, M., Kimura, M., and Fujimura, M. 2009. Characterization of QoI resistance in Botrytis cinerea and identification of two types of mitochondrial cytochrome $b$ gene. Plant Pathol. 58:120-129.

Bartlett, D. W., Clough, J. M., Godwin, J. R., Hall, A. A., Hamer, M., and ParrDobrzanski, B. 2002. The strobilurin fungicides. Pest Manage. Sci. 58:649-662.

Beck, A., Ritschel, A. K., Schubert, K., Braun, U., and Triebel, D. 2005. Phylogenetic relationships of the anamorphic genus Fusicladium s. lat. as inferred by ITS nrDNA data. Mycol. Prog. 4:111-116.

Belfort, M., and Roberts, R. 1997. Homing endonucleases: Keeping the house in order. Nucleic Acids Res. 25:3379-3388.

Bertrand, P. F. 2002. Scab. Pages 55-57 in: Compendium of Nut Crop Diseases in Temperate Zones. B. L. Teviotdale, T. J. Michailides, and J. W. Pscheidt, eds. American Phytopathological Society, St. Paul, MN.

Brasseur, G., Saribas, A. S., and Daldal, F. 1996. A compilation of mutations located in the cytochrome $b$ subunit of the bacterial and mitochondrial $b c_{I}$ complex. Biochim. Biophys. Acta 1275:61-69.

Brock, J., and Bertrand, P. 2007a. Diseases of pecan in the southeast. Page 171 in: Southeastern Pecan Growers' Handbook. L. Wells, ed. Univ. Ga. Coop. Ext. Bull. 1327.

Brock, J., and Bertrand, P. 2007b. Pecan disease profile: Scab. Pages 185-187 in: Southeastern Pecan Growers' Handbook. L. Wells, ed. Univ. Ga. Coop. Ext. Bull. 1327.

Brock, J., Stevenson, K., and Brenneman, T. 2007. Pecan fungicides and resistance management. Pages 172-175 in: Southeastern Pecan Growers' Handbook. L. Wells, ed. Univ. Georgia Coop. Ext. Bull. 1327.

Cech, T. R. 1988. Conserved sequences and structures of group I introns: Building an active site for RNA catalysis-A review. Gene 73:259-271.

Demaree, J. B. 1924. Pecan scab with special reference to sources of the early spring infections. J. Agric. Res. 28:321-333.

Demaree, J. B., and Cole, J. R. 1929. Behavior of Cladosporium effusum (Wint.) Demaree on some varieties of pecan. J. Agric. Res. 38:363-370.

Fernández-Ortuño, D., Toréz, J. A., de Vicente, A., and Pérez-García, A. 2008. Mechanisms of resistance to QoI fungicides in phytopathogenic fungi. Int. Microbiol. 11:1-9.

Fisher, N., and Meunier, B. 2001. Effects of mutations in mitochondrial cytochrome $b$ in yeasts and man. Eur. J. Biochem. 268:1155-1162.

Fontaine, S., Remuson, F., Fraissinet-Tachet, L., Micoud, A., Marmeisse, R., and Melaya, D. 2009. Monitoring of Venturia inaequalis harboring the QoI resistance G143A mutation in French orchards. Pest Manage. Sci. 65:74-81.

FRAC. 2013. List of plant-pathogenic organisms resistant to disease control agents. CropLife Int., Brussels. Online publication. Fungicide Resistance Action Committee. http://www.frac.info/docs/default-source/publications/listof-resistant-plant-pathogens/list-of-resistant-plant-pathogenic-organisms-february2013.pdf?sfvrsn $=4$

FRAC. 2016. FRAC Code List. CropLife Int., Brussels. Online publication. Fungicide Resistance Action Committee. http://www.frac.info/docs/default-source/publications/ frac-code-list/frac-code-list-2016.pdf?sfvrsn $=2$

Gisi, U., Sierotzki, H., Cook, A., and McCaffery, A. 2002. Mechanisms influencing the evolution of resistance to Qo inhibitor fungicides. Pest Manage. Sci. 58:859-867.
Grasso, V., Palermo, S., Sierotzki, H., Garibaldi, A., and Gisi, U. 2006a. Cytochrome $b$ gene structure and consequences for resistance to Qo inhibitor fungicides in plant pathogens. Pest Manage. Sci. 62:465-472.

Grasso, V., Sierotzki, H., Garibaldi, A., and Gisi, U. 2006b. Characterization of the cytochrome $b$ gene fragment of Puccinia species responsible for the binding site of QoI fungicides. Pestic. Biochem. Physiol. 84:72-82.

Hall, T. A. 1999. BioEdit: A user-friendly biological sequence alignment editor and analysis program for Windows 95/98/NT. Nucleic Acids Symp. Ser. 41: 95-98.

Heath, P. J., Stephens, K. M., Monnat, R. J., Jr., and Stoddard, B. L. 1997. The structure of I-Crel, a group I intron-encoded homing endonuclease. Nat. Struct. Biol. 4:468-476.

Hunter, R. E. 1983. Influence of scab on late season nut drop of pecans. Plant Dis. 67:806-808.

Lambowitz, A. L., and Belfort, M. 1993. Introns as mobile genetic elements. Annu. Rev. Biochem. 62:587-622.

Latham, A. J. 1995. Pecan scab management in humid regions. Pages 41-44 in: Sustaining Pecan Productivity into the 21st Century, Second National Pecan Workshop Proceedings. USDA-ARS.

Littrell, R. H. 1976. Resistant pecan scab strains to benlate and pecan fungicide management. Pecan South 3:335-337.

Littrell, R. H., and Bertrand, P. F. 1981. Management of pecan fruit and foliar diseases with fungicides. Plant Dis. 65:769-774.

Luo, C.-X., Hu, M.-J., Jin, X., Yin, L.-F., Bryson, P. K., and Schnabel, G. 2010. An intron in the cytochrome $b$ gene of Monilinia fructicola mitigates the risk of resistance development to QoI fungicides. Pest Manage. Sci. 66:1308-1315.

Miessner, S., Mann, W., and Stammler, G. 2011. Guignardia bidwellii, the causal agent of black rot on grapevine has a low risk for QoI resistance. J. Plant Dis. Prot. 118:51-53.

Miessner, S., and Stammler, G. 2010. Monilinia laxa, M. fructigena and $M$. fructicola: Risk estimation of resistance to QoI fungicides and identification of species with cytochrome $b$ gene sequences. J. Plant Dis. Prot. 117:162-167.

Schonbaum, G. R., Bonner, W. D., Jr., Storey, B. T., and Bahr, J. T. 1971. Specific inhibition of the cyanide-insensitive respiratory pathway in plant mitochondria by hydroxamic acids. Plant Physiol. 47:124-128.

Seyran, M., Brenneman, T. B., and Stevenson, K. L. 2010a. A rapid method to monitor fungicide sensitivity in the pecan scab pathogen, Fusicladium effusum. Crop Prot. 29:1257-1263.

Seyran, M., Brenneman, T. B., and Stevenson, K. L. 2010b. In vitro toxicity of alternative oxidase inhibitors salicylhydroxamic acid and propyl gallate on Fusicladium effusum. J. Pest Sci. 83:421-427.

Seyran, M., Nischwitz, C., Lewis, K. J., Gitaitis, R. D., Brenneman, T. B., and Stevenson, K. L. 2010c. Phylogeny of the pecan scab fungus Fusicladium effusum $\mathrm{G}$. Winter based on cytochrome $b$ gene sequence. Mycol. Prog. 9:305-308

Siedow, J. N., and Bickett, D. M. 1981. Structural features required for inhibition of cyanide-insensitive electron transfer by propyl gallate. Arch. Biochem. Biophys. 207:32-39.

Sierotzki, H., Frey, R., Wullschleger, J., Palermo, S., Karlin, S., Godwin, J., and Gisi, U. 2007. Cytochrome $b$ gene sequence and structure of Pyrenophora teres and P. tritici-repentis and implications for QoI resistance. Pest Manage. Sci. 63:225-233.

Sierotzki, H., Parisi, S., Steinfeld, U., Tenzer, I., Poirey, S., and Gisi, U. 2000 Mode of resistance to respiration inhibitors at the cyochrome $b c_{1}$ enzyme complex of Mycosphaerella fijiensis field isolates. Pest Manage. Sci. 56: 833-841.

Sparks, D. 1992. Pecan Cultivars: The Orchards Foundation. Pecan Production Innovations, Watkinsville, GA.

Stevenson, K. L., Bertrand, P. F., and Brenneman, T. B. 2004. Evidence for reduced sensitivity to propiconazole in the pecan scab fungus in Georgia (Abstr.) Phytopathology 94:S99.

Tamura, K., Stecher, G., Peterson, D., Filipski, A., and Kumar, S. 2013. MEGA6: Molecular Evolutionary Genetics Analysis Version 6.0. Mol. Biol. Evol. 30: 2725-2729.

Vallières, C., Trouillard, M., Dujardin, G., and Meunier, B. 2011. Deleterious effect of Qo inhibitor compound resistance-conferring mutation G143A in the intron-containing cytochrome $b$ gene and mechanisms for bypassing it. Appl. Environ. Microbiol. 77:2088-2093.

White, T. J., Bruns, T., Lee, S., and Taylor, J. 1990. Amplification and direct sequencing of fungal ribosomal RNA genes for phylogenetics. Pages 315-322 in: PCR Protocols: A Guide to Methods and Application. M. A. Innis, D. H. Gelfand, J. J. Sninsky, and T. J. White, eds. Academic Press, San Diego, CA

Wood, P. M., and Hollomon, D. W. 2003. A critical evaluation of the role of alternative oxidase in the performance of strobilurin and related fungicides acting at the Qo site of Complex III. Pest Manage. Sci. 59:499-511. 